\title{
Literature Review on Corporate Social Responsibility
}

\author{
Rong-Jia SU ${ }^{1, a}$, Xiao-Wen JIE ${ }^{2, b,{ }^{*}}$ \\ 1,2 Business School of Sichuan University, Sichuan, P. R. China \\ asuzansrj@163.com, bjiexw@vip.163.com \\ ${ }^{*}$ Corresponding author
}

\begin{abstract}
Keywords: Corporate social responsibility, Stakeholder, Consumer response.
\end{abstract}
\begin{abstract}
Corporate social responsibility (CSR) has aroused increasing interests from academic field and corporations. While pursuing profits, corporations should also fulfill social responsibilities to advance social well-being, which can in turn contribute to the success of business. The purpose of this study is to systematically assort definitions on CSR, sort out dimensions of CSR used in empirical studies, and analyze studies on outcomes of CSR based on foreign and domestic literature. Limitations of existing studies are discussed and future research directions are suggested.
\end{abstract}

\section{Introduction}

CSR has gained prominence in academic literature and business community in recent years; because businesses are increasingly aware of the role they should perform in the society, in addition to pursue profits. A number of studies have manifested the benefits generated by fulfilling social responsibilities. Positive brand image and reputation can be created through corporate social activities [1]. CSR represent an integral part for adopting differentiation strategy [2,3]. It is also an innovative means for companies to enhance relationship with customers [4]. Under the circumstances, it is of great theoretical and practical significance to examine and review existing literature on CSR. The purpose of this study is to show how CSR has been defined, what dimensions of CSR has been empirically tested and what outcomes can be yielded from fulfilling CSR based on the content analysis of existing CSR literature.

\section{Definitions on CSR}

Plenty of studies have defined CSR from diverse perspectives. Mohr [5] divides definitions on CSR into two types: multi-dimensional definitions and definitions based on social marketing. Multi-dimensional definitions list main social responsibilities for corporations, while social marketing concept views CSR according its impacts on society. Dahlsrud [6] conducts comprehensive analysis on 37 definitions of CSR according to relevant literature from 1980 to 2003, and then groups definitions on CSR into five dimensions, including: the environmental dimension, the social dimension, the economic dimension, the stakeholder dimension and the voluntariness dimension. In this paper, definitions on CSR are categorized into two perspectives based on previous studies: the stakeholder perspective and the social perspective.

The representative of the stakeholder perspective is Freeman, he asserts that businesses have responsibilities for groups and individuals who can both influence and be influenced by business operation [7]. Khoury, Rostami [8] state that CSR encompasses relationship between a company and all of its stakeholders, such as customers, employees, communities, owners/ investors, government, suppliers and competitors. According to them, the major social responsibilities of corporations consist of community service, the improvement of relationship with employees, job creation, environmental protection and financial returns. Hopkins [9] also defined CSR from the stakeholder perspective. He points out that CSR is to treat a company's stakeholders in a moral and responsible way in an effort to attain the two-fold goal of maintaining profit and improving the living standard of stakeholders inside and outside the company. According to Basu and Palazzo [10], CSR is a firm's response to stakeholders' concerns about business operation and social affairs, these 
stakeholders include government, non-governmental organization and consumers.

Davis and Blomstrom [11]define CSR from social perspective, they state that CSR refers to actions taken by a corporation to protect and improve social well-being and corporate interests. According to Kotler [12], CSR means running the firm in a way which can maintain and improve social well-being. McWilliams and Siegel [13] regard CSR as a firm's responsibility to enhance social interests, this responsibility goes beyond laws and the firm's interests. Mohr, Webb [14] further point out that CSR is the commitment made by a company to remove or reduce its adverse impacts on the society, and meanwhile boost the long-term beneficial influences on the society. Matten and Moon [15] define CSR as policies and actions adopt by a corporation to reflect its responsibilities to advance social interests.

\section{Dimensions of CSR Used in Empirical Studies}

Waddock and Graves [16] investigate the relationship between a corporation's social performance and financial performance. They draw upon the 8 index constructed by the firm KLD to measure corporate social performance, 5 of the 8 attributes stress relations with stakeholders, including community relations, environmental protection, relations with employees, treatment of women and minorities, and product attributes. Sen and Bhattacharya [17] empirically study the role of CSR on consumer purchasing behavior, they measure CSR from five dimensions, namely, community involvement, diversity, environment protection, social cause and treatment of overseas employees. Pivato, Misani [18] conduct research on the impact of corporate social performance on consumer trust and brand loyalty. They employ environment dimension, consumer dimension and employee dimension to measure corporate social performance. Abdullah and Rashid [19] assess the impact of CSR implementation on organizational citizenship behavior. Dimensions of CSR adopted in their study encompass CSR to government, CSR to employee, CSR to society, CSR to environmental protection and CSR to customer.

With regard to domestic literature, Wen and Fang [20] carry out empirical study on the relationship between CSR and financial performance based on data from 46 publicly listed companies in China from 2003 to 2007. They measure CSR according to the variety of capital, including responsibilities towards stakeholders of financial capital, human resources capital, social capital and ecological capital. Xie and Zhou [21] investigate the impact of CSR on consumer purchase intention. They measure CSR from five dimensions: the protection of consumer rights and interests, involvement in philanthropy and charitable donation, environment protection, and concern for employee interests. Jin [22] construct a scale to measure CSR from consumer perspective, the scale consists of five dimensions: participation into charitable activities that can benefit society, public welfare undertakings, protection for consumer rights and interests, environmental protection and economic responsibilities. Wang and Li [23] study the influence of different dimensions of CSR on organizational citizenship behavior, and evaluate CSR by three dimensions, including: market responsibility, employee responsibility and public responsibility.

\section{Studies on Outcomes of CSR}

\section{Research on the Impact of CSR on Corporate Financial Performance}

Studies conducted on the correlation between CSR and financial performance have shown divergent results. Roman, Hayibor [24]review 55 articles concerning the relationship between corporate social performance and corporate financial performance, among which, 51 papers are found in the research done by Griffin and Mahon [25], and four articles are newly added. They find that 33 studies indicate a positive relationship between CSP and CFP, 5 studies show a negative relationship, and 14 studies demonstrate no relationship. With regard to studies after 1999,Simpson and Kohers [26] attest to the positive relationship between CSR and financial performance through empirical study. The research conducted by Jo and Harjoto [27] further supports this result. However, according to McWilliams and Siegel [28],CSR exerts a neutral influence on financial 
performance after controlling investment in $R \& D$ as another determinant for financial performance. A number of domestic studies investigate the relationship between CSR and financial performance by taking into consideration of time. Wen and Fang [20]carry out an in-depth analysis on the 5-year data of 46 Chinese firms and prove that CSR has a negative impact on financial performance in the short run, and exerts a positive effect on financial performance in the long run. Zhang, Jin [29] examine the data of non-financial companies listed in Shanghai Stock Exchange from 2007 to 2011 and demonstrate that the fulfillment of CSR over previous years has a positive influence on financial performance at present.

\section{Research on the Influence of CSR on Consumer Response}

An increasing number of studies have been devoted to exploring the relationship between CSR and consumer response. The research carried out by Murray and Vogel [30] shows that consumers are more willing to purchase products from a firm after they learn about the firm's involvement in social activities.Brown and Dacin [31] study two types of corporate associations, one is corporate ability associations and the other one is CSR associations. They point out that different corporate associations reflect different strategic positioning, and a growing number of firms begin to focus their attention on strategies that can display CSR, such as the efforts made by a firm to protect environment, enhance employee diversity, engage in community service and sponsor cultural activities. The results from their research show that CSR associations can indirectly affect consumers' evaluation of products offered by a firm through their assessment of the firm. Following this study, an empirical test presented in the work of Sen and Bhattacharya [17] indicates that the association between CSR and consumers' responses is moderated by consumers' personal support of CSR. They also mention that under certain circumstances, a firm's social activities may undermine consumer purchase intention. Mohr, Webb [14] conduct 48 in-depth interviews with consumers in a metropolis. They find that some consumers behave in a socially responsible way, because they are of the view that their purchase decisions not only influence their families and themselves, but also affect the environment. Therefore, these socially responsible consumers take into account a firm's social activities when making purchase decisions. A number of studies also indicate that consumers could appreciate and reward corporations that have made donations to charities, they hope that corporations can operate in a ethical way in which environment can be protected and sometimes their purchase decisions are based on these factors [32-34].

\section{Strategic Implications of CSR}

According to Hall [35], consumers' cognitive association of a company can become a source of sustainable competitive advantage. This view is further supported by Hart [36], he find that for certain types of companies, fulfillment of CSR in environment can contribute to sustainable competitive advantage. Porter and Kramer [37] examine corporate philanthropy and challenge the view held by Friedman [38] that managers are not supposed to use CSR as a tool to serve their own interests, corporate resources invested in CSR should be used to improve efficiency of the corporation. Porter and Kramer [37] further explain that one implicit assumption of Friedman's argument is that a corporation's social goals and economic goals are separate, thus increasing spending on social activities will undermine economic benefits. However, Porter and Kramer [37] are of the view that competitive context is integral to the success of a corporation, and the context can be improved through charitable causes carried out by the corporation, which can contribute to the integration of the corporation's economic goals and social goals. Meanwhile, they remind corporations to choose charitable causes that are related to their business operation. Otherwise, it can only generate social benefits without bringing economic benefits.

\section{Conclusion and Discussion on Existing Literature on CSR}

On the whole, a substantial number of existing literature on CSR focus on the effects it produce. More empirical tests are needed to investigate determinants of CSR and resources utilized in the provision of CSR. Furthermore, the selection of dimensions of CSR in domestic empirical studies is 
primarily based on foreign literature, and choose dimensions such as community relations, employee relations, diversity, protection of consumer rights and interests, environment protection, product attributes and treatment of women and minority groups [16, 17]. However, the dimension like community relations may not be as influential in China as it is in the U.S. and other European countries, because the concept of community and community relations have not received adequate attention in China. Moreover, different stakeholders show interests to different dimensions of CSR. For instance, consumers may care more about protection of consumer rights and interests, whereas employees might be more interested in employee relations. Thus, future research can develop dimensions and scales that are congruent with the reality in China and examine the effect of different dimensions on different stakeholders.

\section{References}

[1] Hsu K-T. The advertising effects of corporate social responsibility on corporate reputation and brand equity: Evidence from the life insurance industry in Taiwan [J]. Journal of Business Ethics. 2012, 109(2):189-201.

[2] Gardberg NA, Fombrun CJ. Corporate citizenship: Creating intangible assets across institutional environments [J]. Academy of Management Review. 2006, 31(2):329-46.

[3] McWilliams A, Siegel DS, Wright PM. Corporate social responsibility: Strategic implications [J]. Journal of Management Studies. 2006, 43(1):1-18.

[4] Bhattacharya CB, Sen S. Doing better at doing good: When, why, and how consumers respond to social initiatives [J]. California Management Review. 2004, 47(1):9-24.

[5] Mohr LA, editor Corporate social responsibility: competitive disadvantage or advantage? [C]. 1996 Marketing and Public Policy Conference. 1996. Chicago: American Marketing Association.

[6] Dahlsrud A. How corporate social responsibility is defined: an analysis of 37 definitions [J]. Corporate Social Responsibility and Environmental Management. 2008, 15(1):1-13.

[7] Freeman RE. Strategic management: A stakeholder approach [M]. Boston: Pitman, 1984.

[8] Khoury G, Rostami J, Turnbull JP. Corporate Social Responsibility: Turning Words into Action [M]. Ottawa: Conference Board of Canada, 1999.

[9] Hopkins M. The planetary bargain: Corporate social responsibility matters [M]: Earthscan,2003.

[10] Basu K, Palazzo G. Corporate social responsibility: A process model of sense making [J]. Academy of Management Review. 2008, 33(1):122-36.

[11] Davis K, Blomstrom RL. Business and Society: Environment and Responsibility [M]. New York: McGraw-Hill 1975.

[12] Kotler P. Marketing Management: Analysis Planning Implementation and Control (7th ed.)[M]. Englewood Cliffs, NJ: Prentice Hall, 1991.

[13] McWilliams A, Siegel D. Corporate social responsibility: A theory of the firm perspective [J]. Academy of Management Review. 2001, 26(1):117-27.

[14] Mohr LA, Webb DJ, Harris KE. Do consumers expect companies to be socially responsible? The impact of corporate social responsibility on buying behavior [J]. Journal of Consumer Affairs. 2001, 35(1):45-72.

[15] Matten D, Moon J. "Implicit" and "explicit" CSR: A conceptual framework for a comparative understanding of corporate social responsibility [J]. Academy of Management Review. 2008, 
33(2):404-24.

[16] Waddock SA, Graves SB. The corporate social performance [J]. Strategic Management Journal. 1997, 8(4):303-19.

[17] Sen S, Bhattacharya CB. Does doing good always lead to doing better? Consumer reactions to corporate social responsibility [J]. Journal of marketing Research. 2001, 38(2):225-43.

[18] Pivato S, Misani N, Tencati A. The impact of corporate social responsibility on consumer trust: the case of organic food [J]. Business Ethics: A European Review. 2008, 17(1):3-12.

[19] Abdullah MH, Rashid NRNA. The Implementation of Corporate Social Responsibility (CSR) Programs and its Impact on Employee Organizational Citizenship Behavior [J]. International Journal of Business and Commerce. 2012, 2(1):67-75.

[20] Wen SB, Fang Y. Empirical study on the relationship between corporate social responsibility and financial performance--analysis on panel data from stakeholder perspective [J]. China Industrial Economics. 2008(10):150-9.

[21] Xie PH, Zhou ZC. Empirical study on the relationship between corporate social responsibility and consumer purchase intention in China [J]. NanKan Business Review. 2009, 12(1):64-70.

[22] Jin LY. An empirical study on corporate social responsibility evaluating scale system--consumers' viewpoint [J]. China Industrial Economics. 2006(6):114-20.

[23] Wang WB, Li H. The study on the internal mechanism of the impact of corporate social responsibility on organizational citizenship behavior. [J]. China Business and Market. 2012, 11:78-84.

[24] Roman RM, Hayibor S, Agle BR. The Relationship Between Social and Financial Performance Repainting a Portrait [J]. Business \& Society. 1999, 38(1):109-25.

[25] Griffin JJ, Mahon JF. The corporate social performance and corporate financial performance debate twenty-five years of incomparable research [J]. Business \& Society. 1997,36(1):5-31.

[26] Simpson WG, Kohers T. The link between corporate social and financial performance: evidence from the banking industry [J]. Journal of Business Ethics. 2002, 35(2):97-109.

[27] Jo H, Harjoto MA. The causal effect of corporate governance on corporate social responsibility [J]. Journal of Business Ethics. 2012, 106(1):53-72.

[28] McWilliams A, Siegel D. Corporate social responsibility and financial performance: correlation or misspecification? [J]. Strategic Management Journal. 2000, 21(5):603-9.

[29] Zhang ZG, Jin XC, Li GQ. An empirical study on the Interactive and Inter-temporal influence between corporate social responsibility and corporate financial performance [J]. Accounting Research. 2013(8):32-9.

[30] Murray KB, Vogel CM. Using a hierarchy-of-effects approach to gauge the effectiveness of corporate social responsibility to generate goodwill toward the firm: Financial versus nonfinancial impacts [J]. Journal of Business Research. 1997, 38(2):141-59.

[31] Brown TJ, Dacin PA. The company and the product: corporate associations and consumer product responses [J]. The Journal of Marketing. 1997:68-84.

[32] Ross JK, Patterson LT, Stutts MA. Consumer perceptions of organizations that use cause-related marketing [J]. Journal of the Academy of Marketing Science 1992, 20(1):93-7. 
[33] Smith SM, Alcorn DS. Cause marketing: a new direction in the marketing of corporate social responsibility [J]. Journal of Consumer Marketing. 1991, 8(3):45-9.

[34] Creyer EH, Ross Jr WT. The impact of corporate behavior on perceived product value [J]. Marketing Letters. 1996,7(2):173-85.

[35] Hall R. A framework linking intangible resources and capabilities to sustainable competitive advantage [J]. Strategic Management Journal. 1993, 14:607-18.

[36] Hart SL. A natural-resource-based view of the firm [J]. Academy of Management Review. 1995,20 (4):986-1014.

[37] Porter ME, Kramer MR. The competitive advantage of corporate philanthropy [J]. Harvard Business Review. 2002, 80(12):56-68.

[38] Friedman M. The Social Responsibility of Business Is to Increase Its Profits [J]. New York Times. 1970:122-6. 